\title{
LINGUAGEAR NA COMPREENSÃO DA ANÁLISE TEXTUAL DISCURSIVA: DAS PALAVRAS AOS CONCEITOS
}

\section{LANGUAGING IN THE COMPREHENSION OF DISCURSIVE TEXTUAL ANALYSIS: FROM WORDS TO CONCEPTS}

\author{
Andrei Steveen Moreno-Rodríguez ${ }^{1}$
}

\begin{abstract}
Resumo: A análise Textual Discursiva (ATD) tem sido amplamente empregada em diversos estudos durante os últimos anos no Brasil. Esse fato tem gerado uma miríade de sentidos ao redor de sua compreensão. Nessa perspectiva, e com o intuito de promover maiores compreensões a respeito dos fundamentos e procedimentos dessa metodologia, o presente estudo procurou abordar, de forma teórica e introdutória, palavras que constituem um linguagear característico da ATD. Assim, num movimento ascendente - das palavras aos conceitos -, discutem-se palavras que foram indicadas, como termos de difícil compreensão ou de ampla relevância nos estudos sobre essa metodologia, por pós-graduandos que cursaram uma disciplina sobre ATD. Tais termos foram agrupados em três eixos: abordagens filosóficas nos estudos sobre ATD; significação na ATD; percurso analítico na ATD.
\end{abstract}

Palavras-chave: Pesquisa qualitativa; Análise Textual Discursiva; Metodologia; Linguagear.

Abstract: The Discursive Textual Analysis (DTA) has been widely used in several studies in the last years in Brazil. This fact has generated a myriad of senses of its understanding. In this perspective, and in order to promote greater understanding of the foundations and procedures of this methodology, the present study tried to approach, in a theoretical and introductory way, words that constitute a characteristic languaging of the DTA. Thus, in an upward movement - from words to concepts -, words that have been indicated, by postgraduates who have taken a course on DTA, as terms of difficult understanding or of wide relevance in studies on this methodology are discussed. These terms have been grouped into three axis: philosophical approaches in studies of the DTA; meaning in the DTA; analytical path in the DTA.

Keywords: Qualitative research; Discursive Textual Analysis; Methodology; Languaging.

\section{Introdução}

A análise textual discursiva (ATD) (MORAES; GALIAZZI, 2007, 2016) é uma metodologia de análise de informações qualitativas que, durante os últimos anos, tem se apresentado como importante protagonista em pesquisas das áreas de Educação e Ensino no Brasil. Trata-se de uma metodologia que tem por finalidade produzir novas compreensões sobre fenômenos e discursos.

A rápida disseminação dessa metodologia, sendo empregada para o desenvolvimento de dissertações, teses e diversos trabalhos científicos, em diferentes regiões do país, tem gerado uma miríade de sentidos em torno da sua compreensão. Isto

\footnotetext{
${ }^{1}$ Doutor em Educação em Ciências pela Universidade Federal do Rio Grande do Sul (UFRGS).
} Universidade Estadual de Santa Cruz (UESC), Ilhéus, BA, Brasil. E-mail: wontola48@gmail.com 
se deve a que, ao estudar sobre ATD, pesquisadores iniciantes defrontam-se com o uso de palavras que não tinham estudado anteriormente ou que não são comumente usadas, o que torna complexa sua compreensão.

Considerando que as palavras são símbolos da linguagem e que todos os seres humanos nos constituímos nela, ou seja, que estamos desde sempre submetidos ao funcionamento da linguagem e que nunca tivemos uma só experiência que não fosse mediada por ela (SANTOS; BORGES; LOPES, 2019), compreende-se que é por meio da linguagem que novas compreensões em relação à ATD podem ser alcançadas.

Para Maturana (1988), a linguagem constitui o domínio em que se apresentam todas as condutas e ações humanas. No entanto, o autor assinala que a palavra linguagem é um substantivo que só adquire significado no fluir do conviver (MATURANA, 2002, 2004), e, nessa perspectiva, propõe usar o verbo linguagear para se referir ao modo de viver característico dos seres humanos, que, em conjunto com o emocionar, permite que aprendamos e nos transformemos (VAZ, 2008).

Este estudo, por estar inspirado no conviver de uma experiência acadêmica em que discentes de mestrado cursaram uma disciplina intitulada "Análise Textual Discursiva: fundamentos teóricos e metodológicos", procura discutir, de forma teórica e introdutória, palavras que constituem um linguagear característico da ATD.

Entende-se que as palavras como estruturas fundamentais do linguagear, tornamse "lugar de significados e sentidos sempre passíveis de maior compreensão" (GALIAZZI; SOUSA, 2019, p. 2). Nessa perspectiva, objetiva-se, por meio de um movimento ascendente - das palavras aos conceitos -, promover maiores compreensões sobre os fundamentos filosóficos e o percurso analítico da ATD.

\section{Das palavras aos conceitos}

$\mathrm{Na}$ busca de ampliação de compreensões e com base na dialética, dois movimentos analíticos podem ser realizados: a) um descendente, em que se procura, a partir de uma realidade, no seu todo, a emissão de uma palavra que seja a mais apropriada a ela; b) um ascendente, da palavra ao conceito, em que, de forma lógica e teórica, procuram-se diferentes significados atribuídos à palavra em questão (GADAMER, 2000, RODHEN, 2012).

Neste estudo, foca-se a atenção no segundo movimento, o ascendente, para o qual Rodhen (2012) descreve cinco momentos que o compõem, a saber: 1) nome ou 
palavra; 2) definição; 3) imagem ou exemplo; 4) inteligência ou opinião verdadeira; 5) o objeto, a coisa mesma.

Para o autor, os três primeiros movimentos possuem afinidade entre si e constituem uma estratégia metodológica para à interpretação, enquanto o quarto e o quinto momento possuem caraterísticas próprias e estão atrelados ao sujeito. No caso do quarto momento, não se trata de "um novo elemento, independente e diverso dos três primeiros, mas sim a transferência deles ao lado do sujeito" (RODHEN, 2012, p. 119). O quinto momento é a "coisa" em si mesma, que realmente existe. Porém, esta "coisa" não pode ser entendida como algo exterior ao sujeito que a conhece, pois, esse conhecimento depende da afinidade do sujeito com o objeto (RODHEN, 2012).

Tendo em conta o anterior, neste estudo, realiza-se um movimento analítico ascendente, apenas entre o primeiro e o terceiro momento: parte-se das palavras e suas etimologias; apresentam-se definições contemporâneas das mesmas; e, discutem-se os termos com base em exemplificações ou contribuições presentes na literatura. Isso com o intuito de abrir os caminhos para o desenvolvimento do quarto e do quinto momento e, dessa forma, promover a ampliação das compreensões do leitor sobre conceitos ligados à ATD.

Cabe salientar que, para Rodhen (2012, p. 119), os quatro primeiros momentos,

$$
\begin{aligned}
& \text { constituem e tramam as condições para alcançar o conhecimento perfeito do } \\
& \text { quinto. } \mathrm{O} \text { alcance desse último ocorrerá apenas se aqueles forem apreendidos } \\
& \text { num todo e articulados entre si numa perspectiva conjunta e crescente de } \\
& \text { compreensão da coisa [mesma]. Participam da compreensão do real à medida } \\
& \text { que explicitam suas qualidades e apontam sua essência, porém, não revelam } \\
& \text { ainda a coisa mesma, não permitem possuir seu entendimento total nem sua } \\
& \text { conceitualização apropriada aos seus contornos porque a linguagem - o } \\
& \text { nome, a definição, a imagem e também a ciência dos objetos - é limitada } \\
& \text { porque somos finitos. Por outro lado, do ponto de vista do objeto - a } \\
& \text { intelecção da coisa não acaba nem se esgota, pois ela mesma é insondável; do } \\
& \text { ponto de vista de quem conhece, não é possível apreendê-la totalmente. }
\end{aligned}
$$

Nesse sentido, não se pretende aqui chegar a definições absolutas e indiscutíveis sobre as palavras que constituem o linguagear na ATD, mas ampliar os horizontes de compreensão dessa metodologia de análise. Partiu-se de palavras que foram indicadas por discentes de pós-graduação como termos relevantes ou que foram de difícil compreensão durante o transcurso da disciplina "Análise Textual Discursiva: fundamentos teóricos e metodológicos”. Essas palavras foram apontadas pelos discentes por meio de uma lista que foi solicitada ao final da disciplina. 
Dessa lista, foram selecionadas as palavras que mais foram enfatizadas para serem analisadas e discutidas neste estudo. Essas palavras foram agrupadas em três eixos de análise, como apresentados no quadro 1.

Quadro 1: Palavras selecionadas e agrupadas por eixo

\begin{tabular}{|c|c|}
\hline Eixo & Palavra \\
\hline \multirow{2}{*}{ Abordagens filosóficas nos estudos sobre ATD } & Fenomenologia \\
\hline & Hermenêutica \\
\hline \multirow{3}{*}{ Significação na ATD } & Significante \\
\hline & Significado \\
\hline & Sentido \\
\hline \multirow{3}{*}{ Percurso analítico da ATD } & Descrever \\
\hline & Interpretar \\
\hline & Argumentar \\
\hline
\end{tabular}

Fonte: elaborado elo autor

Entretanto, antes de iniciar com o movimento analítico ascendente das palavras, considera-se necessário apontar as principais características da ATD, de forma a construir uma ideia geral dos momentos e procedimentos próprios dessa metodologia.

\section{Apontamentos iniciais sobre Análise Textual Discursiva}

A ATD, proposta por Moraes e Galiazzi (2007), é uma metodologia de análise que possibilita a compreensão dos fenômenos investigados a partir de um processo estruturado, principalmente, em três momentos:

a) Unitarização, que consiste na desmontagem dos textos a serem analisados para a seleção de unidades de significado (fragmentos) relevantes para a pesquisa;

b) Categorização, um processo de agrupamento de elementos textuais (unidades de significado e outros) com significados próximos, que se constitui a partir de categorias a priori (preestabelecidas teoricamente) ou emergentes (que afloram durante a análise), e que pode ser realizado em três fases: categorização inicial, intermediária e final;

c) Comunicação, que equivale à construção de um metatexto em que se estabelecem pontes entre as categorias construídas e os diferentes elementos textuais com o intuito de expressar, com maior clareza, as novas compreensões sobre o fenômeno estudado. "Nos metatextos estão expressos 
os sentidos lidos de um conjunto de textos e/ou discursos" (MEDEIROS; AMORIM, 2017, p. 257).

Durante o desenvolvimento dos três momentos descritos anteriormente, acontece o movimento analítico, no qual a descrição, a interpretação e a argumentação se fazem presentes. Nele, as informações empíricas e os aportes teóricos se entrelaçam por meio da escrita, sendo esta última uma importante ferramenta mediadora na produção de significados (MORAES; GALIAZZI, 2007, 2016).

Na ATD, a intenção desse movimento analítico é "de construção e reconstrução de compreensões sociais e culturais relativas ao fenômeno que investiga" (MORAES; GALIAZZI, 2016, p. 169), portanto, trata-se de um processo Fenomenológicohermenêutico. Esse processo se inicia pela abordagem dos significados e sentidos mais próximos dos fenômenos que investiga e, gradativamente, envolve sentidos mais distantes e complexos (MEDEIROS; AMORIM, 2017, p. 252). A ATD, então, "pretende envolver-se em movimentos de constante reconstrução de significados e dos discursos que investiga" (MORAES; GALIAZZI, 2016, p. 149).

\section{Abordagens filosóficas nos estudos sobre ATD}

Ao solicitar, aos discentes, palavras que foram mais relevantes ou difíceis de compreender durante os estudos da disciplina, dois dos termos expressos pelos discentes foram: fenomenologia e hermenêutica. Esses termos apontam para o enfoque teórico e filosófico da pesquisa com ATD.

Entende-se como enfoque de pesquisa o conjunto de ideias que conduzem o pesquisador nas suas escolhas. Este determina-se pela forma em que o pesquisador compreende a natureza do conhecimento e sua construção. A partir dele, definem-se os métodos e técnicas que serão utilizados para estudar determinado fenômeno. Na ATD, o enfoque de pesquisa constitui-se na Fenomenologia e na Hermenêutica, correntes filosóficas que trazem consigo uma série de contribuições que determinam as características do processo analítico.

\subsection{Fenomenologia}

Segundo sua etimologia (Figura 1), é possível dizer que a palavra fenomenologia corresponde ao logos do fenômeno, ou seja, ao estudo daquilo que que se percebe nos sentidos ou na consciência. A definição contemporânea desses termos - fenômeno e 
fenomenologia (Figura 2) - apresenta uma ideia muito próxima dessa descrição etimológica anterior. No entanto, ao comparar as figuras 1 e 2, é possível notar divergência nas informações no que se refere à origem da palavra fenomenologia.

Figura1: Síntese etimológica das palavras fenômeno e fenomenologia

Fenômeno: 'tudo que é percebido pelos sentidos ou pela consciência' 'Maravilha, raridade'. Do latim tardio Phaenomenon, derivado do grego phainómenon.

Fenomenologia: composta pela palavra fenómeno + a terminação -logia (estudo de)(logos = palavra, tratado; $-i a=$ qualidade) é um vocábulo criado por J.H. Lambert, em 1764, e difundido por Hegel em 1804.

Fonte: Adaptado de Anders et al., (2020) e Cunha (2012)

Figura 2: Definição das palavras fenômeno e fenomenologia

Fenômeno: Aquilo que se oferece à observação intelectual, isto é, à observação pura.

Fenomenologia: No sentido geral, estudo descritivo de um conjunto de fenômenos. Em filosofia moderna, movimento filosófico inaugurado por Husserl para fundamentar a filosofia como ciência rigorosa, capaz de dar base, por sua vez, às próprias ciências em suas condutas específicas. Trata-se de voltar "às próprias coisas" a fim de captar suas essências ao final da redução eidética (1). Ciência dos fenômenos como distintos da natureza do ser; estudo da consciência e de objetos da experiência direta (2).

Fonte: Adaptado de Gregório (2020)

Corrêa (1997) esclarece que J.H. Lambert usou pela primeira vez o termo fenomenologia em 1764, inicialmente compreendido como teoria da aparência ou visão falsa da realidade. A autora explica que em Hegel a fenomenologia definiu-se como método e filosofia, no entanto, atribui a Husserl (1859-1938) a significação do termo como método de aprender e dizer sobre os fenômenos (a realidade manifesta).

Segundo Lima (2014), para Husserl, a fenomenologia é uma ciência sem a qual não seria possível a existência de nenhuma filosofia, pois todo conhecimento se reduz ao que aparece, aos fenômenos, tudo aquilo que se desvela ao sujeito que interroga. A fenomenologia, então, pretende compreender o mundo a partir de sua "facticidade". Nessa perspectiva, na ATD é promovida a valorização do "sujeito e suas manifestações, transparecendo de forma acentuada o exercício de uma atitude fenomenológica de deixar os fenômenos se manifestarem” (MORAES; GALIAZZI, 2016, p. 171).

Assim, na ATD, a análise de informações foca-se na facticidade e na manifestação dos fenômenos, naquilo que se apresenta, naquilo que se mostra e que é percebido pelo pesquisador, neste caso, por meio das palavras, da linguagem. Para Bicudo (2011), essas manifestações da linguagem constituem-se como descrições de experiências vividas, pois os textos e os discursos revelam o dito em contextos culturais nos quais o pesquisador procura compreender realidades. 
A fenomenologia é também o estudo das essências, pois procura compreender o "sentido das coisas, dirigindo o conhecimento para o que há de essencial nelas" (LIMA, 2014, p. 13). "Estudos desta natureza podem ser entendidos como examinando os fenômenos de dentro, de uma perspectiva interna" (MORAES; GALIAZZI, 2016, p. 171). Portanto, é necessário "trabalhar com sentidos e significados que não se dão em si, mas que vão se constituindo e se mostrando em diferentes modos, de acordo com a perspectiva do olhar e na temporalidade histórica de suas durações e respectivas expressões" (BICUDO, 2011, p. 41). Desse modo, a ATD aproxima-se também da hermenêutica filosófica, possibilitando a valorização de múltiplas perspectivas e interpretações acerca dos fenômenos que se investigam.

\subsection{Hermenêutica}

Hermes era o mensageiro dos deuses gregos, "o intérprete da vontade divina, com capacidade de se movimentar para lugares distantes, levar mensagens e trazer consigo a possibilidade de compreensão" (ALVES, 2011, p 19). Assim, a etimologia da palavra hermenêutica (Figura 3) relaciona-se com a mitologia grega, atribuindo-lhe a ideia da troca de mensagens, de apresentar o oculto e de interpretar.

Figura 3: Síntese etimológica da palavra hermenêutica

Hermenêutica: Do latim tardio Hermeneutǐca, derivado do grego hermēneutikē. Relacionado com hermeuta, 'exegeta, intérprete' e com Hermes, da mitologia grega Hermēs, filho de Zeus e Maia, que era o mensageiro dos deuses e o protetor dos viajantes.

Fonte: Adaptado de Cunha (2012)

"A hermenêutica provém de uma longa tradição humanística, relacionada à interpretação dos textos bíblicos, à jurisprudência e à filosofia clássica. Desse modo, refere-se à arte de extrair sentidos explícitos ou ocultos de textos religiosos, jurídicos ou literários" (ALVES, 2011, p.18). No entanto, a hermenêutica ressurge na modernidade como uma possibilidade de oposição à ideia de uma única forma de acesso à verdade, contra o positivismo científico dominante. 
Figura 4: Definição da palavra hermenêutica

Hermenêutica: 1. Termo originalmente teológico. Designando à interpretação ou exegese dos textos antigos, especialmente dos textos bíblicos. 2. O termo passou depois a designar todo esforço de interpretação científica de um texto difícil que exige uma explicação. No século XIX, Dilthey vinculou o termo "hermenêutica a sua filosofia da "compreensão vital": as formas da cultura, no curso da história, devem ser apreendidas através da experiência íntima de um sujeito; cada produção espiritual é somente o reflexo de uma cosmovisão (Weltanschauung) e toda filosofia é uma "filosofia de vida". 3. Contemporaneamente a hermenêutica constitui uma reflexão filosófica interpretativa ou compreensiva sobre os símbolos e os mitos em geral.

Fonte: Japiassú e Marcondes (2001)

Assim sendo, A hermenêutica "reivindica dizer o mundo a partir da sua finitude e historicidade, de onde decorre seu caráter interpretativo" (ALVES 2011, p 18), um ato cultural.

Para Gadamer (2015), não é possível desconsiderarmos as tradições históricas, pois elas nos constituem à medida que somos no mundo. Isto porque somos com os outros nos enredamentos dialógicos, ao buscarmos acordos com outros sujeitos. Ao removermos as tradições históricas e os sujeitos de uma investigação, somos vendados pelas ideias progressivistas, desenvolvimentistas e de objetivação do fenômeno extrínseco ao investigador, limitando nosso horizonte interpretativo em uma atualidade centrada no pesquisador que não busca compreensão, mas apenas uma comprovação, uma verificação daquilo por ele já dominado em seu tempo histórico (SOUSA; GALIAZZI, 2016, p. 40).

Desse modo, ao inserir-se no mundo da linguagem, a hermenêutica se afasta das pretensões de conhecimento do mundo por meio de dados objetivos e "reconhece que pertencemos às coisas ditas, aos discursos, abrindo uma infinidade de interpretações possíveis, próprias" (ALVES, 2011, p. 19; SOUSA; GALIAZZI, 2016).

Sousa e Galiazzi (2016) identificaram na obra Análise Textual Discursiva alguns elementos que se relacionam diretamente com a hermenêutica,

O primeiro é referente às interpretações realizadas pelo pesquisador em que o outro precisa ser considerado; o segundo à imitação como iniciação interpretativa, e o terceiro corresponde à ideia de (re)construção teórica a partir daquilo que emerge da experiência fenomenológica com os sujeitos de pesquisa (SOUSA; GALIAZZI, 2016, p. 44).

Dessa maneira, na ATD, o pesquisador não se encontra só, pois valoriza os sujeitos, seus modos de expressão e seus aportes. Nesse processo de reconhecimento, o pesquisador apoia-se em ideias e teorias, em diferentes interpretações de um mesmo fenômeno e, com base nesse conjunto de interpretações, busca a compreensão. Isto é, a "reconstrução de significados a partir das perspectivas de uma diversidade de sujeitos envolvidos nas pesquisas" (MORAES; GALIAZZI, 2016, p. 167).

A Análise Textual Discursiva tem como fundamento hermenêutico a valorização dos sujeitos e seus modos de expressão a partir do exame interno dos fenômenos. Para isto, é necessário, na (re)construção teórica de 
significados, considerar a diversidade dos sujeitos da pesquisa que estão articulados em redes coletivas de significados sobre as quais o pesquisador é desafiado a compreender, a descrever e a interpretar (SOUSA; GALIAZZI, 2016, p. 42).

Portanto, todo pesquisador deve permanecer aberto e disposto a aprender com o(s) outro(s), pois, as pesquisas realizadas por meio de ATD tornam-se processos de aprendizagem que transformam o pensamento do próprio pesquisador com base no pensamento de outros sujeitos. "A hermenêutica expõe essa abertura e aponta a história e a linguagem como elementos essenciais de acesso ao mundo e ao aprendizado" (ALVES, 2011, p. 17).

Assim, na ATD, o pesquisador deve assumir a posição de interprete, mas, também, a posição de autor (MORAES; GALIAZZI, 2007, SOUSA; GALIAZZI, 2016). "O interpretar constitui modo de teorização. Nesse movimento cíclico hermenêutico de procura de mais sentidos, tanto a teoria auxilia no exercício da interpretação, quanto a interpretação possibilita a construção de novas teorias" (MORAES; GALIAZZI, 2016, p. 59).

\section{Significação na ATD}

Na ATD, a interpretação hermenêutica e a compreensão dos fenômenos se produz a partir de um processo cíclico de atribuição de significados. Nesse processo, três conceitos jogam um papel fundamental: significado, significante e sentido. Essas palavras apareceram constantemente no decurso da disciplina, são usadas regularmente na literatura sobre ATD e foram apontadas na lista elaborada pelos discentes.

\subsection{Significante, significado e sentido}

Figura 5: Síntese etimológica das palavras significado e significante

Significante: Do latim significāns-āntis “que representa uma ideia, fato ou sentimento". Seus componentes léxicos são: signa (sinal, marca), facere (fazer) e o sufixo -nt- (agente). É o agente, a parte fônica ou a imagem acústica, de um fonema ou sequência de fonemas, provido de significação.

Significado: Do latim significātus “objeto, ação, relação, ideia ou emoção que se transmite de uma pessoa para outra”. É a representação, na linguagem, do significante.

Fonte: Adaptado de Anders et al., (2020) e Cunha (2012)

Etimologicamente, o significante seria o elemento (agente) perceptível ou tangível do signo, ou seja, o elemento material que se vê ou ouve (palavra ou imagem). Já o significado corresponderia ao conteúdo, ao que é representado pela palavra, ou seja, o conceito ou a parte abstrata do signo. 
Segundo Japiassú e Marcondes (2001, p. 174),

o estruturalismo linguístico, a partir do linguista suíço Ferdinand de Saussure (1857-1913) estabelece uma distinção entre significado e significante. Segundo essa concepção o signo lingüístico resulta da combinação de uma imagem acústica (o significante) e de um conceito (o significado), que formam na verdade uma unidade indissolúvel, dois aspectos da mesma realidade do signo.

Então,

O significante é uma representação sonora do vocábulo, ele não é um som material, mas sim a impressão psíquica desse som. Ele está relacionado à imagem acústica, é uma tradução fônica de um conceito e é sensorial. O significado é um conceito, pode ser representado, está diretamente ligado a uma ideia ou pensamento e é totalmente psíquico e não psicofísico, como o outro (XAVIER, 2014, p. 91).

Xavier (2014) explica que a ligação entre significado e significante trata-se de uma questão de arbitrariedade, pois as palavras não se relacionam diretamente com o conceito e o valor das coisas. A autora traz como exemplo o conceito "sol", o qual não está exclusivamente ligado aos sons da palavra "s-o-l"- que é seu significante -, pois essa palavra é diferente em outros idiomas sem que isso mude o conceito. Nessa perspectiva, o significante é atribuído arbitrariamente, a depender do contexto cultural em que é construído e de um sistema linguístico específico. "Portanto, não há nenhum significante verdadeiro, qualquer um pode ser valido, depende do idioma" (XAVIER, 2014, p. 91).

Como consequência dessa arbitrariedade, é possível que significantes se desliguem de significados ou que possam unir-se a outros significados quaisquer. "Dessa forma a união que resulta num signo não é eterna, um significante não está colado a um significado, isso permite que uma língua se transforme, permite a variabilidade de sons e sentidos" (CUNHA, 2008, p. 4). Consequentemente, significantes e significados são passíveis de interpretação, suscetíveis de análise.

Segundo Japiassú e Marcondes (2001, p. 174),

A teoria do significado, em filosofia da linguagem, examina os vários aspectos de nossa compreensão das palavras e expressões linguísticas e dos signos em geral. Um desses aspectos centrais é a relação de referência, que é um dos elementos constitutivos do significado. A referência é precisamente a relação entre o signo linguístico e o real, o objeto designado pelo signo.

Dessa maneira, aparece também a noção de "sentido", que, para os mesmos autores, corresponde ao modo pelo qual a referência é feita. Por exemplo, um mesmo termo como "Carnaval", festa religiosa antiga de despedida ao consumo de carne por quarenta dias, pode ser também definido como uma comemoração coletiva em razão de 
alguma situação especial (ANDERS et al., 2020; DICIO, 2020). Assim, as duas situações apresentam a mesma referência, mas não o mesmo significado. A compreensão do significado, portanto, está ligada aos tipos de uso que uma palavra ou expressão pode ter em contextos diferentes, ou seja, ao sentido.

Figura 6: Definição da palavra sentido

O termo sentido pode ser utilizado também como sinônimo de significação (ex.: Não entendi o sentido do que ele disse). Alguns filósofos da linguagem, como Frege, distinguem o sentido (Senn) de uma palavra ou expressão de sua referência (Bedeutung), isto é, do objeto designado. Para Frege o sentido é o modo pelo qual se designa o objeto.

Fonte: Japiassú e Marcondes (2001)

A interpretação hermenêutica, como discutido anteriormente, contempla a diversidade de sentidos possíveis num texto. Isto porque "os textos não carregam um significado a ser apenas identificado; trazem significantes exigindo que o leitor ou pesquisador construa significados a partir de suas teorias e pontos de vista" (MORAES; GALIAZZI, 2016, p. 39)

Desse modo, na ATD, a primeira etapa de "desmontagem dos textos é mostrada como processo recursivo de mergulho nos significados dos textos analisados, processo em que se exige que o pesquisador se assuma em suas interpretações" (MORAES; GALIAZZI, 2016, p. 13 - 14). Essa primeira etapa, mediada pela leitura, permite a aproximação inicial do pesquisador com a diversidade de sentidos que podem ser construídos em relação a um mesmo texto. Nas etapas subsequentes, a partir da maior impregnação do pesquisador com os materiais de análise e por meio de um ciclo hermenêutico, outros sentidos são construídos.

Para Moraes e Galiazzi (2016, p. 37), “a multiplicidade de significados possíveis de construir a partir de um mesmo conjunto de significantes tem sua origem nos diferentes pressupostos teóricos que cada leitor utiliza em suas leituras". Portanto,

\footnotetext{
se um texto pode ser considerado objetivo em seus significantes, não o é nunca em seus significados e sentidos. Todo texto possibilita uma multiplicidade de leituras; leituras essas relacionadas com as intenções dos autores, com os referenciais teóricos dos leitores e com os campos semânticos em que se inserem (MORAES; GALIAZZI, 2016, p 35).
}

Na ATD, os materiais textuais constituem um conjunto de significantes aos quais o pesquisador atribui sentidos e significados. Esse processo acontece "a partir da interação de diferentes vozes, incluída principalmente a do próprio pesquisador" (MORAES; GALIAZZI, 2016, p. 15). O pesquisador, dessa forma, torna-se autor e os significados construídos por ele durante a análise são comunicados na última etapa, na 
estruturação do metatexto. Nessa perspectiva, o pesquisador interfere nos discursos sociais conjugando interlocuções pessoais, empíricas e teóricas (MORAES; GALIAZZI, 2007).

\section{Percurso analítico da ATD}

O percurso analítico na ATD, na busca de atribuição de sentidos, constitui-se a partir de três procedimentos: a descrição, a interpretação e a argumentação. Estes procedimentos, embora sejam realizados com base numa determinada organização e possuam entre eles uma certa hierarquização (ou exijam procedimentos cognitivos diferentes), podem se apresentar, por vezes, de forma concomitante. A discussão sobre esse percurso analítico inicia-se pela palavra descrever.

Figura 7: Síntese etimológica da palavra descrever

Descrever: Do latim describěre, "expor, contar minuciosamente, traçar, seguir percorrendo". Seus componentes léxicos são o prefixo de- (direção de cima a baixo) e scribere (marcar, escrever) significando "escrever sobre a fora em que algo se percebe".

Fonte: Adaptado de Anders et al., (2020) e Cunha (2012)

Figura 8: Definições da palavra descrever

Descrever: 1. Fazer a descrição de; representar por meio de palavras: Descreveu minuciosamente a casa onde morava. 2. Expor em detalhes; contar, expor, narrar: Descreveu-me a sua precária situação. 3. Percorrer (um corpo que se desloca em movimento) uma linha; percorrer, perfazer: Os planetas do sistema solar descrevem uma trajetória elíptica. 4. Desenhar graficamente; riscar, traçar: A boa coordenação motora da criança faz com que ela descreva um círculo perfeito.

Fonte: Michaelis (2020)

Como é possível observar na síntese da figura 7 e nas definições e exemplos da figura 8, “descrever algo é um esforço que se dá no sentido de expor, de registrar ou explicar, porém, sem atribuir a priori valores de análise" (MEDEIROS; AMORIM, 2017, p.250). Ou seja, um esforço baseado na percepção.

No processo analítico da ADT, a descrição é um movimento continuo no qual, por meio da linguagem, o próprio sujeito pesquisador se dá conta de como o fenômeno se mostra. Com a descrição do perceptível, o pesquisador passa a notar suas précompreensões e preconceitos, um primeiro passo para a construção de novos conhecimentos (SOUSA; GALIAZZI, 2018).

Porém, a descrição não aparece exclusivamente no início do processo de análise, ela está presente durante a construção de categorias e na comunicação dos resultados. A 
descrição permite expressar de forma organizada os significados construídos durante a análise.

É expor os elementos constituintes de um fenômeno e as relações existentes entre eles, a partir do que foi compreendido com base nas análises. As descrições necessitam ser logicamente estruturadas, o que é garantido a partir do sistema de categorias e subcategorias construídas na categorização.

As descrições precisam ser densas, com intensas ancoragens na realidade empírica. Isso garante, ao mesmo tempo sua validade e contextualização. É especialmente nas descrições que são importantes as interlocuções empíricas com os sujeitos da pesquisa (MORAES; GALIAZZI, 2016, p. 120).

Para Bicudo (2011, p. 46), na descrição detalha-se "o movimento dos atos da consciência. Ela se limita a relatar o visto, o sentido, ou seja, a experiência como vivida pelo sujeito". No entanto, a autora destaca que na fenomenologia procura-se transcender o que é individualmente descrito, avançando na busca da estrutura, da essência das experiências descritas. Como esse processo se dá mediante a linguagem, dinâmica e mutável, a descrição não é suficiente, é necessário um trabalho interpretativo hermenêutico, trazendo a complexidade das relações entre signos, significantes, significados, sentidos e contextos histórico-culturais (BICUDO, 2011)

Manifesta-se, então, a palavra interpretar (figura 9), cuja etimologia a expõe como algo que está além da descrição, pois exige uma posição do pesquisador, uma representação própria do objeto estudado.

Figura 9: Síntese etimológica da palavra interpretar

Interpretar: Do latim interpretārī, 'traduzir, ajuizar da intenção, do sentido, representar como ator, exprimir o pensamento. É um derivado da palavra interpretis que originalmente significa intermediário em um negócio de compravenda.

Fonte: Adaptado de Anders et al., (2020) e Cunha (2012)

$\mathrm{Na}$ definição contemporânea (Figura 9), os significados do termo interpretar aparecem diversificados.

Figura 10: Definição da palavra interpretar

Interpretar: 1. Determinar com precisão o sentido de um texto 2. Descobrir o significado obscuro de algo. 3. Dar determinado sentido a; julgar. 4. Desempenhar um papel; representar. 5. Traduzir oralmente um texto de um idioma para outro. 6. Cantar ou executar uma peça musical.

Fonte: Michaelis (2020)

Alguns desses significados são discutidos por Alves (2011) tendo em conta que a interpretação é o conceito central na hermenêutica filosófica. $\mathrm{O}$ autor apresenta a complexidade do processo interpretativo a partir de três orientações: dizer, traduzir e explicar. Para o autor, 
O dizer refere-se ao papel anunciador de Hermes. Significa também o estilo como a coisa se exprime. Isso indica que as grandes obras foram feitas para serem ditas e ouvidas e que a linguagem, em seu sentido originário, é mais ouvida que escrita; o explicar enfatiza o aspecto discursivo da compreensão, daquilo que explica, que se torna claro, mais do que aquilo que se expressa. Explicar é uma forma de interpretar; e o traduzir traz à tona uma forma especial de tornar compreensível o mundo. Aquilo que é estranho, estrangeiro, torna-se compreensível, superando a distância. O traduzir supõe a existência de dois mundos, o do autor e o do leitor, os quais devem se tornar compreensíveis (ALVES, 2011, p. 19).

Outras referências da palavra interpretar são observadas na figura 10. Destacamse as últimas três, pois se relacionam com atividades profissionais e/ou habilidades artísticas: representação atoral, tradução linguística e execução musical. Nota-se que essas três atividades denotam uma posição de quem as realiza, um conhecimento prévio e um ato de tornar "seu" aquilo que foi produzido por outro. Então, na interpretação, a interação de diferentes vozes tem lugar, destacando especialmente a voz do pesquisador. Do mesmo modo em que um músico interpreta uma obra alheia e atribui a ela sua identidade, o pesquisador deve mostrar sua identidade nas análises que realiza e comunica por meio do metatexto.

\begin{abstract}
A parte da produção escrita que apresenta as interpretações do pesquisador expressa as novas relações e inferências entre os elementos constituintes de um fenômeno identificadas durante a análise, expõe novos sentidos e significados, explorando e explicitando dinâmicas cada vez mais profundas dos fenômenos (MORAES; GALIAZZI, 2016, p. 122).
\end{abstract}

$\mathrm{Na}$ busca de validar suas interpretações, o pesquisador comunica seus resultados, apoiando-se em razões e justificativas de natureza empírica e teórica. Constitui-se, assim, uma terceira dimensão do percurso analítico da ATD, a argumentação. No metatexto, descrição e interpretação se integram por meio de argumentos bem estruturados, representando as contribuições originais do pesquisador (MORAES; GALIAZZI, 2007).

Figura 11: Síntese etimológica das palavras argumento e argumentar

Argumento: Do latim argūmentum, raciocínio pelo qual se tira uma consequência ou dedução. Argumentar: Do latim argumentare, discutir, esclarecer. Suas componentes léxicas são argueire (deixar claro), -mento (meio, resultado), -ar (usado para formar verbos).

Fonte: Adaptado de Anders et al., (2020) e Cunha (2012)

$\mathrm{O}$ verbo argumentar está relacionado com a raiz indo-europeia $\mathrm{arg}$-, presente em palavras como argentum (plata, por seu brilho). Nesse sentido, como apresentado na síntese etimológica (Figura 11), poderia se dizer que argumentar é um meio para deixar algo claro (dar brilho, iluminar) (FONSECA, 2016; ANDERS et al., 2020). 
Figura 12: Definição das palavras argumento e argumentar

Argumento: 1. Raciocínio, razão ou arrazoado por meio do qual se pretende provar ou refutar a procedência ou veracidade de uma afirmação. 2. Aquilo que atesta a veracidade de alguma coisa; demonstração, indício, prova.

Argumentar: 1. Apresentar fatos, provas ou argumentos. 2. Tirar as consequências de um princípio ou fato; concluir, deduzir. 3. Expor como argumento; aduzir, alegar.

Argumentação: Modo de apresentar e de dispor os argumentos, vale dizer, os raciocínios destinados a provar ou a refutar determinada proposição, um ponto de vista ou uma tese qualquer. Seu objetivo é o de convencer ou persuadir, mostrando que todos os argumentos utilizados tendem para urna única conclusão.

Fonte: Adaptado de Japiassú e Marcondes (2001) e Michaelis (2020)

$\mathrm{Na}$ definição contemporânea das palavras argumento, argumentar e argumentação (Figura 12), aparece a ideia de produção de razões ou provas para defender um ponto de vista, uma proposição. Nessa perspectiva, para chegar na argumentação acontece primeiro um processo de enunciação, no qual, as ideias interiores de um locutor são exteriorizadas para que um receptor as interiorize, atribuindo-lhes um sentido (TEIXEIRA, 2015). Trata-se de uma situação comunicativa, concreta, produzida num contexto específico, em que se apresentam a construção, a recepção e a circulação de sentidos e significados.

Desse modo, a enunciação, que possui um caráter social e histórico, pois envolve relações humanas, encontra-se ligada à significação.

\begin{abstract}
Em cada enunciado - da réplica monovocal do cotidiano às grandes e complexas obras de ciência ou de literatura - abrangemos, interpretamos, sentimos a intenção discursiva de discurso ou a vontade discursiva do falante, que determina o todo do enunciado, o seu volume e as suas fronteiras. Imaginamos o que o falante quer dizer, e com essa ideia verbalizada, essa vontade verbalizada (como a entendemos), é que medimos a conclusibilidade do enunciado. Essa ideia determina tanto a própria escolha do objeto (em certas condições de comunicação discursiva, na relação necessária com os enunciados antecedentes) quanto os seus limites e a sua exauribilidade semântico-objetal. Ele determina, evidentemente, também a escolha da forma do gênero na qual será construído o enunciado (BAKHTIN, 2003, p. 281).
\end{abstract}

A significação é, desse modo, o produto da interação entre o locutor e o receptor da mensagem por meio dos enunciados. Não se trata apenas do que foi dito, mas da intencionalidade e do contexto tanto do locutor, quanto do receptor da mensagem. (TEIXEIRA, 2015).

A significação, portanto, encontra-se ligada à possibilidade de produzir conclusões. O locutor busca agir sobre os interlocutores, procura chamar sua atenção para se fazer entender. Isto é, ao produzir enunciados, o locutor produz argumentos e 
busca, ainda que não intencionalmente, convencer ou direcionar o pensamento do receptor das mensagens.

Dessa maneira, a argumentação pode ser entendida como um ato de persuasão em que há construção de sentidos, ligados à subjetividade, aos sentimentos e à temporalidade. No entanto, argumentar não se trata apenas de persuadir ou convencer, é um processo no qual o locutor raciocina e estrutura seu pensamento de forma a comunicar melhor suas ideias e nesse processo reflete sobre seu próprio conhecimento.

ao argumentar, o indivíduo é levado a formular claramente seus pontos de vista e fundamentá-los para apresentar razões que sejam aceitáveis a interlocutores. O indivíduo precisa pensar sobre o que vai dizer, considerar quem são os interlocutores, fundamentar pontos de vista. Esse movimento potencializa a produção/apropriação reflexiva de conhecimento. Em outras palavras, formular ponto de vista e fundamentá-los é um mecanismo de produção/apropriação reflexiva de conhecimento. Examinar ponto de vista oposto ao apresentado requer que os indivíduos ouçam, reflitam, concordem, reafirmem ou gerem um novo ponto de vista. O exame de ponto de vista implica em rever conteúdo, ou reafirmando-o ou transformando-o, e, assim, gera-se um novo estado de apropriação, de entendimento sobre o tema (TEIXEIRA, 2015, p. 193).

Em vista disso, a dimensão argumentativa na ATD, promove, além da justificação de ideias e conclusões, a ampliação dos horizontes compreensivos do pesquisador. Contudo, é necessário indicar de que forma acontece a argumentação nesta metodologia de pesquisa, pois, diferentemente da pesquisa quantitativa, a defesa das ideias não é realizada por meio de números ou de estatísticas, se dá por meio de razões e fatos, podendo ser teóricos e/ou empíricos. No caso dos empíricos, trata-se do "uso de 'citações' de elementos extraídos dos textos do corpus. A inserção crítica de excertos bem-selecionados dos textos originais constitui uma forma de validação dos resultados das análises" (MORAES; GALIAZZI, 2016, p. 61).

As ideias a serem defendidas por meio de argumentos e apoiadas em fragmentos de texto empíricos são apesentadas na etapa final da ATD, a comunicação, por meio da construção de um metatexto, no qual o desafio é conseguir expressar ideias originais acompanhadas de argumentos sólidos. Nesse sentido, "a produção escrita é um movimento de constituição de pensamentos próprios, argumentos originais, movimento que vai dos textos ao contexto, do inconsciente ao consciente" (MORAES; GALIAZZI, 2016, p. 117).

Um bom texto vai da descrição e narrativa para a interpretação e argumentação. Segundo Demo (2001) a extensão se descreve; a profundidade solicita argumentos. Os argumentos vão além das descrições e das categorias. Por isso volta-se a enfatizar que uma produção escrita de qualidade precisa girar em torno de uma tese, uma hipótese ou ponto de vista que o pesquisador assume defender, modificações que ele produz no discurso existente. [...] 
Ainda que a argumentação no seu sentido retórico vise a convencer, é importante que se produza num contexto de construção de autonomia, propiciando a todos ampliarem sua participação nos discursos, sempre de forma crítica e fundamentada. A autonomia aqui apontada não é de caráter individual, mas de sujeitos participantes de um mesmo discurso e capazes de se assumirem sujeitos, manifestando sua própria voz no contexto de outras vozes. Nisso se enquadra, também, o próprio pesquisador (MORAES; GALIAZZI, 2016, p. 125).

O pesquisador, por conseguinte, deve construir e empregar argumentos pertinentes e coerentes para defender as conclusões alcançadas durante a análise. É com base nisso que os autores da ATD assimilam a metodologia com o uso de "uma vara de condão capaz de transformar fragmentos dispersos de texto em conjuntos de argumentos estruturados e fundamentados, permitindo transformar palavras soltas em sonoros poemas" (MORAES; GALIAZZI, 2016, p. 16, grifo do autor).

\section{Algumas considerações}

Por meio de discussões teóricas, foi possível abordar, de forma introdutória, palavras e conceitos que são fundamentais para a compreensão da ATD como metodologia de análise de informações qualitativas. A abordagem dessas palavras e seu uso constante nos estudos sobre ATD constituem um linguagear característico da metodologia.

Nos estudos sobre ATD, durante a disciplina que inspirou este trabalho, o linguagear e o emocionar estiveram constantemente presentes, desvelando, em vários momentos, dificuldades para a compreensão da metodologia. Portanto, ao abordar palavras e conceitos representativos da metodologia ou que foram de difícil compreensão para os discentes, por meio de sínteses etimológicas e descritivas, este estudo buscou promover maiores compreensões sobre os fundamentos teóricofilosóficos, o percurso analítico e os procedimentos da ATD.

A base empírica deste estudo, em conjunto com a configuração da escrita acadêmica, limitou as possibilidades de levantar discussões sobre outras palavras usadas na ATD, que também fazem parte do linguagear nos estudos sobre esta metodologia, a saber: dialética, categoria, emergência, compreensão, discurso, entre outras. Portanto, espera-se que tais palavras e metáforas sejam abordadas em estudos posteriores.

Neste estudo, o caminho metodológico adotado partiu das palavras para promover a chegada aos conceitos. No entanto, para Gadamer (2000, p. 23), "compreender significa que eu posso pensar e ponderar o que o outro pensa", ou seja, 
para obter novas compreensões é necessário colocar-se no lugar do outro. Assim sendo, é necessário percorrer o caminho na outra direção, dos conceitos às palavras, possibilitando a compreensão de uns para com os outros.

\section{Agradecimentos}

Agradeço aos discentes que participaram no desenvolvimento da disciplina "Análise Textual Discursiva: fundamentos teóricos e metodológicos" do PPGCEM/UESC.

Agradeço à professora Maria do Carmo Galiazzi por me incentivar a percorrer os caminhos de compreensão da ATD.

\section{Referências}

ALVES, M. A. Da hermenêutica filosófica à hermenêutica da educação. Acta Scientiarum. Education, Maringá, v. 33, n. 1, p. 17-28, 23 maio 2011.

ANDERS, V. et al. Diccionário etimológico Castellano em Línea, 2020. Disponivel em: http://etimologias.dechile.net/. Acesso em: 28 out. 2020.

BAKHTIN, M. M. Estética da Criação Verbal. 4. ed. São Paulo: Martins Fontes, 2003.

BICUDO, M. A. V. Pesquisa qualitativa fenomenológica: interrogação, descrição e modalidades de análise. In: BICUDO, M. A. V. (org.). Pesquisa qualitativa segundo a visão fenomenológica. São Paulo: Editora Cortez, 2011. p. 41-74.

CORRÊA, A. K. Fenomenologia: uma alternativa para pesquisa em enfermagem. Rev latinoam. Enfermagem (online), Ribeirão Preto, v. 5, n. 1, 1997.

CUNHA, A. G. Dicionário etimológico da língua portuguesa. 4. ed. Rio de Janeiro: Lexikon Editora, 2012.

CUNHA, R. B. A relação significante e significado em Saussure. Revista Virtual de Estudos da Linguagem - ReVEL, [S.I.], ed. especial, v. 6, n. 2, p. 1-14, nov. 2008.

DICIO. Dicionário Online de Português. 2009 - 2020. Disponível em: https://www.dicio.com.br/. Acesso em: 26 out. 2020.

FONSECA, F. G. C. Os operadores argumentativos como estratégia linguística e discursiva da argumentação na sentença judicial. 2016. 103f. Dissertação (Mestrado em Estudos da Linguagem) - Centro de Ciências Humanas, Letras e Artes, Universidade Federal do Rio Grande do Norte, Natal, 2016.

GADAMER, H. Da palavra ao conceito. In: ALMEIDA, C.; FLICKINGER, H.; ROHDEN, L. Hermenêutica Filosófica: nas trilhas de Hans-Georg Gadamer. Porto Alegre: EDIPUCRS, 2000. p. $13-26$ 
GALIAZZI, M. do C.; SOUSA, R. S. de. A dialética na categorização da análise textual discursiva: o movimento recursivo entre palavra e conceito. Revista Pesquisa Qualitativa, São Paulo, v.7, n.13, p. 1-22, abr. 2019.

GREGÓRIO, S. B. Dicionário de filosofia. 2020. Disponível em:

https://sites.google.com/view/sbgdicionariodefilosofia/p\%C3\%A1gina-inicial?authuser=0.

Acesso em: 28 out. 2020.

JAPIASSÚ, H.; MARCONDES, D. Dicionário Básico de Filosofia. 3. ed. rev. e amp. Rio de Janeiro: Zahar, 2001.

LIMA, A. B. M. O que é fenomenologia?. In: LIMA, A. B. M. (org.). Ensaios sobre

fenomenologia: Husserl, Heidegger e Merleau-Ponty. Ilhéus: Editus, 2014. p. 9-14

MATURANA, H. Ontología del conversar. Revista terapia Psicológica, [S.I.], ano 2, v. 10, p. $1-14,1988$.

MATURANA, H. A ontogenia da realidade. Belo Horizonte: Ed. UFMG, 2002.

MATURANA, H. Entrevista. Centro de Ciências de Educação e Humanidade, Universidade Católica de Brasília, v. 1, n. 2, s.p. nov. 2004. Disponível em:

https://filosoficabiblioteca.files.wordpress.com/2013/10/entrevista-com-maturana.pdf. Acesso em: 25 out. 2020.

MEDEIROS, E. A.; AMORIM, G. C. C. Análise textual discursiva: dispositivo analítico de dados qualitativos para a pesquisa em educação. Laplage em Revista, Sorocaba, v. 3, n. 3, p. 247- 260, set.-dez. 2017.

MICHAELIS. Dicionário Brasileiro da Língua Portuguesa (online). Editora Melhoramentos. 2015 - 2020. Disponível em: https://michaelis.uol.com.br/moderno-portugues/creditos/. Acesso em: 25 out. 2020.

MORAES, R.; GALIAZZI, M. do C. Análise textual discursiva. Ijuí: Editora Unijuí, 2007.

MORAES, R.; GALIAZZI, M. do C. Análise textual discursiva. 3. ed. Rev. e Ampl. Ijuí: Editora Unijuí, 2016.

ROHDEN, L. Filosofando com Gadamer e Platão. Dissertatio, Pelotas, v. 36, p. 105-130, 2012.

SANTOS, G.; BORGES, V.; LOPES, A. C. Formação de professores e reformas curriculares: entre projeções e normatividade. Linhas Críticas (online), Brasília, v. 25, p. 239-256, 15 jul. 2019.

SOUSA, R. S.; GALIAZZI, M. do C. Compreensões acerca da Hermenêutica na Análise Textual Discursiva: Marcas Teórico-Metodológicas à Investigação. Revista Contexto \& Educação, Ijuí, v. 31, n. 100, p. 33-55, set./dez. 2016.

SOUSA, R. S.; GALIAZZI, M. do C. O jogo da compreensão na análise textual discursiva em pesquisas na educação em ciências: revisitando quebra-cabeças e mosaicos. Ciênc. educ., Bauru, v. 24, n. 3, p. 799-814, sept. 2018.

TEIXEIRA, F. M. É possível argumentação sem controvérsia? Ensaio Pesquisa em Educação em Ciências, Belo Horizonte, v. 17, n. especial, p. 187-203, nov. 2015. 
VAZ, N. O linguagear é o modo de vida que nos tornou humanos. Cienc. Cult., São Paulo, v. 60, n. spe1, p. 62-67, jul. 2008.

XAVIER, G. do C. Significante e significado no processo de alfabetização e letramento: contribuições de Saussure. Cadernos CESPUC de Pesquisa Série Ensaios, Belo Horizonte, v. 1, n. 25, p. 87-102, dez. 2014.

Recebido em: 02 de novembro de 2020.

Aceito em: 25 de novembro de 2020. 